\title{
Пам'яті члена-кореспондента НАМН України, заслуженого діяча науки і техніки України, доктора медичних наук, професора Юрія Івановича Губського
}

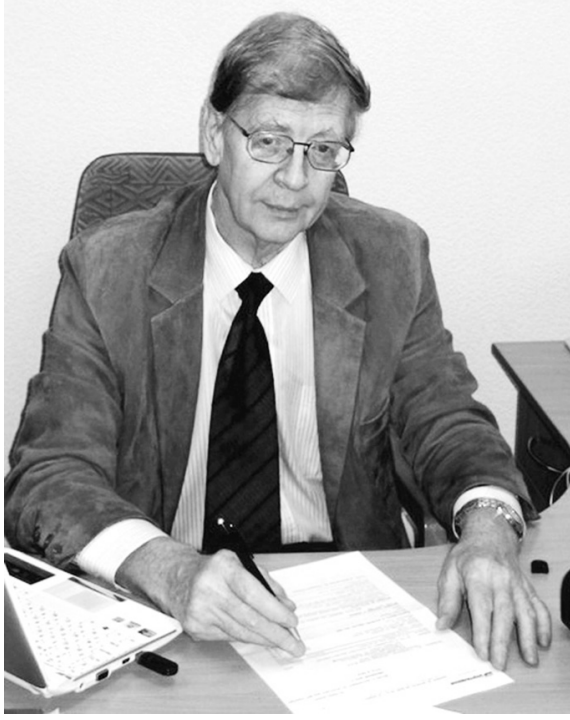

18 травня 2019 року пішов з життя видатний український учений, членкореспондент НАМНУ, заслужений діяч науки і техніки України, доктор медичних наук, професор Юрій Іванович Губський.

Юрій Іванович Губський народився 1 жовтня 1945 року в м. Харкові. Навчався в Харківському медичному інституті, на медико-біологічному факультеті 2-го Московського медичного інституту ім. М. I. Пирогова (фах - біофізика), механіко-математичному факультеті Харківського державного університету, з 1966 року - у Київському медичному інституті імені О. О. Богомольця (КМI). Наукові дослідження розпочав у студентські роки під керівництвом видатного українського біохіміка, одного з перших учнів академика О. В. Палладіна, члена-кореспондента АН УРСР А. М. Утевського. Після закінчення в 1969 році лікувального факультету КMI (нині Національний медичний університет імені О. О. Бого- мольця) навчався в аспірантурі кафедри біохімії КМI (1969-1972 рр.). У 1972-1987 роках - науково-педагогічна робота в КМI (асистент, доцент, професор кафедри біоорганічної та біологічної хімії, завідувач Центральної науково-дослідної лабораторії КМI). Доктор медичних наук з 1984 року, професор з 1987 року.

У 1987-1991 роках професор Ю. І. Губський - заступник директора з наукової роботи Київського НДІ фармакології та токсикології (КНДІФТ) МОЗ УРСР; у 1991-1992 роках - в. о. директора КНДІФТ (нині ДУ «Інститут фармакології та токсикології НАМНУ»), у якому майже протягом 30 років (з 1988 р.) очолював лабораторію та (з 1993 р.) відділ біохімічної фармакологіï.

Ю. І. Губський - один із засновників і перший заступник голови Фармакологічного комітету МОЗУ (19911993 рр.), головний вчений секретар та один з організаторів (під керівництвом академіка О. Ф. Возіанова) Академії медичних наук України (19931997 pp.).

у 1992-2000 роках Ю. І. Губський на науково-організаційній та адміністративній роботі - начальник управління та атестаційного відділу медичних, біологічних, хімічних та аграрних наук Вищої атестаційної комісії (ВАК) при Кабінеті Міністрів України, завідувач кафедри біоорганічної, біологічної та фармацевтичної хімії (1997-2010 рр.) та один із засновників фармацевтичного факультету Національного медичного університету імені О. О. Богомольця.

З 2008 року - директор створеного за його ініціативою ДП «Інститут паліа- 
тивної та хоспісної медицини МОЗУ », з 2010 року - завідувач кафедри паліативної та хоспісної медицини Національної медичної академії післядипломної освіти імені П. Л. Шупика, з 2014 року - директор Державного навчально-науково-методичного центру паліативної та хоспісної медицини Національної медичної академії післядипломної освіти імені П. Л. Шупика.

У 2016-2019 роках - начальник науково-координаційного управління Президії Національної академї медичних наук України.

Основні напрями наукової діяльності Ю. І. Губського та його наукової школи пов'язані 3 вивченням молекулярних механізмів пошкодження біомембран i геному клітини за оксидативного стресу в умовах хімічної патології та старіння організму, пошуком нових фізіологічно активних сполук антиоксидантної дії.

Ю. I. Губський - один 3 перших дослідників у галузі біохімічної токсикології, що наприкінці 1970-х років довів вільнорадикальну природу цитохром Р-450-залежної біотрансформації хлоралканів біоцидної дії. На підставі вивчення розподілу (компартменталізації ) і транспорту іонів $\mathrm{Ca}^{2+}$ у субклітинних структурах обгрунтував перекисно-кальцієву теорію загибелі клітини за ураження високотоксичними ксенобіотиками, у тому числі хлорованими вуглеводнями та фосфорорганічними сполуками.

Пріоритетними розробками Ю. І. Губського та його співробітників є дослідження, присвячені біохімічним механізмам некротичної та апоптотичної загибелі клітин печінки та головного мозку за токсичного пошкодження ДНК, квантовій біохімії та квантовій фармакології антиоксидантів фенольної структури та похідних $\mathrm{N}$-гетероциклів, молекулярним і патофізіологічним механізмам розвитку больового синдрому.

Останніми роками Ю. І. Губський займався питаннями використання новітніх біомедичних технологій у паліативній і хоспісній медицині, орга- нізації системи та служби паліативної допомоги населенню в Україні, пошуком нових фізіологічно активних сполук зі знеболювальною активністю та вдосконаленням нормативної бази застосування опіоїдних аналгетиків у паліативній онкології, створенням формулярів лікарських засобів для застосування в паліативній медицині, брав участь у розробці настанов і клінічних протоколів з контролю больового синдрому в онкології.

Ю. І. Губський є автором понад 650 наукових робіт, у тому числі широко відомих наукових монографій і довідників, зокрема, «Коррекция химического поражения печени» (1989р.), "Химические катастрофы и экология» (1993 р.), «Лекарственные средства в психофармакологии» (1997р.), «Фармакотерапія в паліативній та хоспісній медицині» (2012р.), «Смерть клетки: свободные радикалы, некроз, апоптоз» (2015 р.), 51 патенту та авторського свідоцтва на нові фізіологічно активні сполуки та лікарські засоби з антидотною, антиоксидантною та протипухлинної дією.

Ю. І. Губський є автором перших україномовних підручників для студентів вищих медичних та фармацевтичних навчальних закладів III-IV рівнів акредитації, а саме: "Біологічна хімія» (2000 р., 2008 р., 2011 р.), «Біоорганічна хімія» (2004 р.) та навчальних програм для вищих навчальних закладів держави з цих дисциплін.

Під його науковим керівництвом та консультуванням підготовлено 19 докторських і 13 кандидатських дисертацій з біохімії, фармакології, токсикології та клінічних дисциплін.

Юрій Іванович - автор літературних мемуарів «Как это было. От Союза до моей Украины» (2010р.), книги прозових творів «По Сумской и дальше...» (2014 р.), науково-історичних, публіцистичних і літературних публікацій у періодичних виданнях.

Член-кореспондент НАМНУ Ю. І. Губський очолював створену за його ініціативою Проблемну експертну комісію МОЗУ і НАМНУ «Біологічна та медична 
хімія», був членом спеціалізованих вчених рад у провідних медико-біологічних установах України, головним редактором науково-практичного журналу «Медична та клінічна хімія», науковим редактором журналу «Медична реабілітація та паліативна допомога», членом редакційної ради журналу «Фармакологія та лікарська токсикологія», редакційних колегій часописів «Журнал Національної академії медичних наук України», «Український біохімічний журнал», «Фармацевтичний журнал» .

Незаперечним визнанням наукових заслуг Ю. І. Губського було його обрання в 1994 році членом-кореспондентом Академії медичних наук України та присвоєння в 1997 році почесного звання «Заслужений діяч науки і техніки України" за заслуги у становленні національної системи атестації наукових i науково-педагогічних кадрів вищої кваліфікації, багаторічну наукову діяльність. Ю. І. Губський - лауреат академічних премій НАМНУ з профілактичної медицини (1997р.) і теоре- тичної медицини (2007 р.). Нагороджений орденом «За розбудову України» на честь 25-річчя Національної академії медичних наук України (2018р.) та орденом преподобного Агапіта Печерського І ступеня (2013 р.).

Юрій Іванович Губський завжди був сповнений творчими планами та задумами, до останніх днів життя продовжував багато працювати. Творчість, талант, натхнення, інтелект, відданість справі, притаманні його яскравій особистості, позначилися на професійному житті багатьох людей, його колег та учнів.

Будемо пам'ятати Юрія Івановича Губського як талановитого вченого, людину глибоких і різносторонніх знань, учителя!

ВГО «Асоціація фармакологів України»

ДУ «Інститут фарлакологї та токсикологї НАМН України» Редколегія журналу «Фармакологія та лікарська токсикологія» 